\title{
Taxation and Budget Reform Commission (TBRC) Statutory Recommendation: Expansion of Faith- and Character-Based Initiatives in Florida's Correction System ${ }^{1}$
}

Rodney L. Clouser²

A series of 16 fact sheets has been written on statutory and constitutional proposals adopted by the Taxation and Budget Reform Commission (TBRC). The publications in this series can be accessed at http://edis.ifas.ufl.edu. Fact sheets FE733 through FE741 address statutory changes and fact sheets FE742 through FE748 address constitutional amendments. These fact sheets should not be considered as an all-inclusive assessment of the statutory or constitutional changes recommended by the Taxation and Budget Reform Commission. Some details of proposed changes may not have been discussed due to space limitations. These fact sheets are not intended as a replacement for personal knowledge about actual or proposed changes but are a guide to inform the public on the issues.

\section{Introduction}

The Taxation and Budget Reform Commission (TBRC) has made a statutory recommendation to the Florida Legislature concerning expansion of faithand character-based initiatives in Florida's correction system. The transmittal letter to the President of the Florida Senate and Speaker of the House specifically states that the TBRC "recommendation authorizes and encourages the Department of Corrections to expand faith- and character-based programs at correctional institutions." The measure also expresses intent that transition assistance programs for ex-offenders be "funded from the cost savings."

\section{TBRC Recommendations}

The proposed recommendation by the TBRC amends Chapter 944.803 of the Florida Statutes and explicitly notes that faith- and character-based correctional institutions meet state principles of public safety, acclimating people incarcerated to the prison system; help those incarcerated take responsibility for their actions; and reduce the number of repeat offenders.

Currently, several conditions exist before inmates can participate in the faith- and

1. This is EDIS document FE738, a publication of the Food and Resource Economics Department, Florida Cooperative Extension Service, Institute of Food and Agricultural Sciences, University of Florida, Gainesville, FL. Published July 2008. Please visit the EDIS website at http://edis.ifas.ufl.edu.

2. Rodney L. Clouser, professor and extension public policy specialist of the Food and Resource Economics Department, Florida Cooperative Extension Service, Institute of Food and Agricultural Sciences, University of Florida, Gainesville, FL.

The Institute of Food and Agricultural Sciences (IFAS) is an Equal Opportunity Institution authorized to provide research, educational information and other services only to individuals and institutions that function with non-discrimination with respect to race, creed, color, religion, age, disability, sex, sexual orientation, marital status, national origin, political opinions or affiliations. U.S. Department of Agriculture, Cooperative Extension Service, University of Florida, IFAS, Florida A. \& M. University Cooperative Extension Program, and Boards of County Commissioners Cooperating. Larry Arrington, Dean 
character-based programs. Some examples of those conditions include the following: inmates must have had no disciplinary actions against them in the 90 days preceding program enrollment; inmates must be in general-population housing status; and inmate participation must be voluntary, not compulsory. These conditions are retained.

The state currently has three faith- and character-based correctional institutions, which are located in Lawtey, Hillsborough, and Wakulla Counties. Courses offered at these institutions by secular and religious groups include family skills (e.g., parenting and fatherhood), business and technology skills (e.g., computer and financial classes), and personal skills (e.g., anger management and goal setting). The TBRC recommendations explicitly state that the Department of Corrections (DOC) is to "continue to improve and expand the existing" programs in Lawtey and Hillsborough Counties and to expand the program in Wakulla County to "include the main unit, work camp, and annex."

DOC is also encouraged to expand the number of volunteers, as well as partnerships with groups such as colleges, universities, and other community institutions and businesses. Cost savings, although no explicit amount is mentioned, generated from the faith- and character-based programs should then be used to transition inmates back into their communities when released. According to staff analysis, DOC is to "evaluate the benefits, implications, and realistic limitations of the faith- and character-based prison model for cost savings, crime reduction ...."

\section{Impact of Proposed Statutory Change}

Some individuals believe faith- and character-based programs are beneficial for a variety of reasons that range from optimal staffing of correctional institutions to cost savings generated from the program. In general, the constraints placed on those inmates participating in the program would result in different staffing patterns in prisons. The inmates are relatively low risk, are housed in the general population, and have had no disciplinary actions against them within the 90 days preceding program enrollment. Some argue that, since inmates volunteer for the program, only those who are somewhat accountable and accept responsibility for the actions that resulted in their imprisonment will participate. Therefore, skilled and trained staff within prisons can be freed up to work with higher risk inmates.

Some people might also argue that inmates participating in these programs are less likely to be repeat offenders. This is why the recommendation by the TBRC suggests that a portion of cost savings, as a result of fewer repeat offenders, could be used to transition inmates back into their local communities. Increasing partnerships and volunteers also has the potential to reduce some costs and, at the same time, build community partnerships and ownership of programs. Cooperation among the public, private, and religious sectors might be viewed positively by many people. Of course, some individuals might also argue that special programs for those who have committed criminal acts are inappropriate. Finally, it may be argued by some that these programs will make inmates released from the state correctional system more successful as they transition back into local communities.

There is a possibility that some people might argue that actions such as those suggested by the TBRC violate the concept of separation of church and state as established in both the U.S. and Florida Constitutions. However, staff analysis indicated that Florida DOC procedures assure compliance with both the national and state constitutions.

\section{Summary}

Although the statutory recommendations have been made by the TBRC, and in some instances with specific dates to become effective, the Florida Legislature and the Governor are not bound to the effective dates or the recommendations. Before these recommendations become law, they require approval of both the Florida Senate and House, and approval by the Governor. Citizens interested in the specific recommendations will need to follow the progress of the issue through the legislative process.

Additionally, there is no time limit for action by the legislature on the TBRC recommendations and they 
can be introduced in future legislative sessions if not passed during the current session.

\section{References}

Florida Taxation and Budget Reform

Commission. 2008. SR0019: an act relating to faithand character-based prisons. TBRC, Tallahassee, FL (April).

http://www.floridatbrc.org/pdf/SR0019_final.pdf

Florida Taxation and Budget Reform

Commission. 2008. SR 19 Staff Analysis and

Economic Impact Statement. TBRC, Tallahassee, FL

(April).

http://www.floridatbrc.org/pdf/

$\underline{\text { SR0019StaffAnalysis.pdf }}$

Florida Taxation and Budget Reform

Commission. 2008. Transmittal letter. TBRC,

Tallahassee, FL (April).

http://www.floridatbrc.org/pdf/

3_18_08TransmittalLtrSR19.pdf

State of Florida. 2008. Faith-based programs for inmates. Florida Statute 944.803. Florida

Legislataure, Tallahassee, FL.

http://www.flsenate.gov/Statutes/

index.cfm?App_mode=Display_Statute\&URL=Ch09

$\underline{44}$

titl0944.htm\&StatuteYear=2007\&Title $=\% 2 \mathrm{D} \% 3 \mathrm{E} 200$

7\%2D\%3EChapter\%20944 